\title{
ABOUT SOME SOCIAL AND HEALTH PROBLEMS OF PERSONS, SEEKING INTERNATIONAL PROTECTION ON THE TERRITORY OF THE REPUBLIC OF BULGARIA
}

\author{
Hristina Milcheva', Albena Andova', Mariya Dimova ${ }^{3}$
}

\begin{abstract}
The influx of migrants to European countries, including the Republic of Bulgaria, is constantly increasing from regions experiencing military conflicts and countries that are economically undeveloped. At present, the Republic of Bulgaria is regarded by asylum seekers as a transit state on their route to the economically developed European countries. The people seeking asylum in the European Union have different sociocultural, ethnical, religious, and health cultures. These differences make their adaptation to their new environment difficult and the situation creates economic, social, and health problems for the accepting countries. The enforcement of uniform European standards and laws for social and health integration of migrants facilitates the process and protects the local people from infectious diseases and social-economic problems. The analysis of documents of the European Union, from international and Bulgarian organizations, shows policies have been developed to guarantee the rights of individuals, seeking protection. A major issue for the successful adaptation of migrants is their unwillingness to observe the laws and regulations of the countries where they settle.
\end{abstract}

UDC Classification: 614.1, DOI: http://dx.doi.org/10.12955/cbup.v4.788

Keywords: migration, asylum seekers, social problems, health problems.

\section{Introduction}

According to the United Nations High Commissioner for Refugees (UNHCR), an asylum-seeker is a person who claims to be a refugee and seeks international protection from persecution or grave encroachment in their native countries (UNHCR, 2015). Every refugee initially seeks asylum. However, not every asylum seeker is ultimately approved as a refugee. While waiting for their applications to be approved (or denied), such a person is called "an asylum seeker" (UNHCR, 2015).

A refugee is a person who:

having reasonable fear of persecution by reason of race, religion, nationality or belonging to a certain social group or for political convictions, who is outside the country of their citizenship and who cannot benefit from protection of this country or is not willing to benefit from such protection by reason of these fears; or, being without citizenship and being outside the country of their former habitual residence as a result of similar events, cannot return or, as a result of such fears, is not willing to return to it. (State Agency for Refugees with the Council of Ministers, 1993)

According to the June 17, 2015 report of the UNHCR, a new dangerous era of resettlement, worldwide, has begun with almost 60 million people having been banished from their homes (UNHCR, 2015). The report shows that the number of resettled people, as a result of wars, conflicts, and persecution, has reached its highest level ever registered, and furthermore, it is accelerating. The global tendencies show a rapid increase in the number of people banished from their homes. Whereas until the end of 2014 this number was 59.5 million, only a year earlier it was 51.2 million, and ten years previous to this, 37.5 million.

According to the data of the UNHCR (2015), the number of people banished from their homes in 2014 compared to 2013 was the highest difference ever registered between years. In 2014, the daily average of individuals becoming refugees, asylum seekers, or domestically resettled persons (DRP) was 42500 , which represented a quadruple increase in only four years (UNHCR, 2015). One in 122 people in the world was a refugee, a DRP, or an asylum-seeker (UNHCR, 2015). If this number was the population of a country, that country would be the 24th largest country in the world (UNHCR, 2015).

\footnotetext{
${ }^{1}$ Hristina Milcheva, Medical College of Trakia University, Stara Zagora, Bulgaria, hr_mil4eva@abv.bg

${ }^{2}$ Albena Andonova, Medical Faculty of Trakia University, Stara Zagora, Bulgaria, andonova_a@dir.bg

${ }^{3}$ Mariya Dimova, Medical College of Trakia University, Stara Zagora, Bulgaria, mdimovameister@gmail.com
} 
Cecilia Malmström, a European Commissioner in charge of the internal affairs, has stated that:

The Common European Asylum System (CEAS) will afford better access to the procedure for obtaining asylum by people seeking protection; it will promote quicker, more qualitative and fair decisions to afford asylum; will guarantee that people, afraid of persecution, would not be returned to the countries where they are endangered and will provide appropriate conditions both for those who apply for asylum and for those who receive international protection in the EU. (European Commission, 2014b)

The enhanced rate of migration to the EU has been evoked by demographic and economic processes, which are combined with effects of climatic change and political and military conflicts in countries from the Near and Middle East, and North Africa.

\section{Methods}

An analysis was undertaken of the documents of the World Health Organization (WHO), the United Nations (UN), the European Union, and Bulgarian state institutions with regards to the social and health problems of persons seeking protection on the territory of the Republic of Bulgaria.

\section{Objective}

In recent years, the political, inter-ethnical, and inter-religious conflicts in the regions adjacent to the European Union have deepened and the number of people needing asylum has continued to increase. Due to the geographic proximity of the Republic of Bulgaria to these countries under pressure, a significant part of the migration wave has been directed towards the Bulgarian borders, with the country gradually and steadily transforming from a country of emigration, as a transit country, to a country attracting immigration (Council of Ministers of the Republic of Bulgaria, 2015).

Table 1: Information from the State Agency for Refugees with the Council of Ministers on number of persons seeking protection and decisions made about them by the Bulgarian authorities

\begin{tabular}{||r|r|r|r|r|r|r|}
\hline Year & $\begin{array}{c}\text { Number of } \\
\text { persons } \\
\text { seeking } \\
\text { protection }\end{array}$ & \multicolumn{1}{c|}{$\begin{array}{c}\text { Awarded } \\
\text { refugee } \\
\text { status }\end{array}$} & \multicolumn{1}{c|}{$\begin{array}{c}\text { Awarded } \\
\text { humanitarian } \\
\text { status }\end{array}$} & Denial & $\begin{array}{c}\text { Terminated } \\
\text { procedure }\end{array}$ & $\begin{array}{c}\text { Total } \\
\text { number of } \\
\text { decisions }\end{array}$ \\
\hline $\mathbf{2 0 1 0}$ & 1025 & 20 & 118 & 386 & 202 & 726 \\
\hline $\mathbf{2 0 1 1}$ & 890 & 10 & 182 & 366 & 213 & 771 \\
\hline $\mathbf{2 0 1 2}$ & 1387 & 18 & 159 & 445 & 174 & 796 \\
\hline $\mathbf{2 0 1 3}$ & 7144 & 183 & 2279 & 354 & 824 & 3640 \\
\hline $\mathbf{2 0 1 4}$ & 11081 & 5162 & 1838 & 500 & 2853 & 10353 \\
\hline $\mathbf{2 0 1 5}$ & 20391 & 4708 & 889 & 623 & 14567 & 20787 \\
\hline $\begin{array}{c}\mathbf{2 0 1 6} \\
\text { Janu } \\
\text { ary }\end{array}$ & 1966 & 47 & 18 & 33 & 1638 & 1736 \\
\hline
\end{tabular}

Source: The State Agency for Refugees with the Council of Ministers (2016)

Based on data of the European Commission and the Ministry of the Interior, in 2014 the Republic of Bulgaria recorded a total of 41506 attempts of illegal border crossing by third-country nationals, with 93\% of these (numbering 38 502) occurring at the Bulgarian-Turkish border. Compared to 2013, the migration pressure had increased 2.3 times. These numbers include attempts that had been prevented by the border police of neighboring countries and migrants who had voluntarily returned after 
approaching the Bulgarian green borders (Bulgarian National Contact Point for the European Migration Network, 2014).

Data of the State Agency for Refugees at the Council of Ministers of Republic of Bulgaria, for January 2016 only, showed the number of persons seeking protection in the country was 1,966 from 13 countries (stateless persons inclusive). Of these, refugee status was awarded to 47 persons from four countries and humanitarian status to 18 persons from two countries, while denial of refugee status was issued to 33 persons from 14 countries (The State Agency for Refugees with the Council of Ministers, 1993).

For the period January 1, 2010 to January 1, 2016, data from the State Agency for Refugees (Table 1) showed an abrupt increase over this time in the number of persons seeking protection and resulting decisions by the Bulgarian authorities (The State Agency for Refugees with the Council of Ministers, 2016).

In the period January 1-31, 2016, an increase in the number of asylum seekers in the Republic of Bulgaria, originating from Iraq and Afghanistan was observed (Table 2; The State Agency for Refugees with the Council of Ministers, 2016).

Table 2: Information of the State Agency for Refugees with the Council of Ministers in regards to the top five countries of origin, according to the number of filed protection applications during the period January 1-31, 2016

\begin{tabular}{|c|c|c|}
\hline Serial number & Country & $\begin{array}{c}\text { Number of filed } \\
\text { applications }\end{array}$ \\
\hline $\mathbf{1 .}$ & IRAQ & 958 \\
\hline $\mathbf{2 .}$ & AFGHANISTAN & 688 \\
\hline $\mathbf{3 .}$ & SYRIA & 218 \\
\hline $\mathbf{4 .}$ & PAKISTAN & 64 \\
\hline $\mathbf{5 .}$ & SOMALIA & 5 \\
\hline
\end{tabular}

Source: The State Agency for Refugees with the Council of Ministers (2016)

\section{Results}

To avoid the threat of increasing migration pressures, the Republic of Bulgaria should undertake measures to guarantee the security of the territory and the population, parallel with undertaking actions to protect the rights of those needing protection and requiring social integration. At present, the Republic of Bulgaria has moderate migration pressure. However, with the closure of the Eastern Balkan corridor, the danger of the immigrant surge being directed towards the Republic of Bulgaria increases considerably.

These migrants originate from different social, ethnical, cultural, racial, economic, and language environments compared with those of Europe and, in particular, that of Bulgaria. Their communication with local people and state authorities is hindered primarily by their inability to speak the language of the country in which they settle.

In addition, there are cultural barriers with migrants having different religious backgrounds, ways of thinking, behavior, and life philosophies to those of local people. Most frequently, the immigrants have no knowledge of the culture of the accepting country, nor are they willing to conform to it. They form closed homogeneous communities and do not relate to the local people easily.

To help avoid any domestic social and economic tension in the country as a result of an increasing migration influx, it is necessary to analyze, in detail, the social and health problems of the persons settling in the territory of a country for asylum and protection. 
The most vulnerable groups of refugees are women, children, aged persons, people with disability, and homosexuals.

Migrants who settle on a permanent basis in a country, encounter difficulties with social and cultural adaptation and in finding work. To a large extent, this is a consequence of their low educational level and the language and cultural barriers that restrict their opportunity for education, as well as their low level of awareness in regards to legislation. This makes them an easy target for recruitment by organized crime syndicates, and obstructs their successful adaptation.

The smugglers and human traffickers can easily take advantage of people without documents. In addition, the "black labor market" attracts illegal immigration. Measures against all forms of illegal immigration are needed to protect the most vulnerable persons and to maintain the public trust in the immigration policies (European Commission, European Union policies, Migration and Asylum, 2014a).

The UNHCR-Bulgaria recommends appropriate measures to create and strengthen harmonic relations with the accepting community through encouraging respect of the asylum seekers and refugees, by forming awareness for their needs and encouraging respect of local culture, traditions, and religion among the asylum seekers, and through provision of basic education in the official language of the accepting country. In addition, it is recommended that the asylum seekers receive consultations on various aspects of admission conditions and participate in the organization of admission centers. Those susceptible in terms of gender and age characteristics need to be identified by the accepting organization, which should consider the specific needs of those who have suffered torture and trauma, the single women, the unaccompanied children, those separated from their families, the families with children at school age, and other vulnerable groups (UNHCR, 2009).

The health problems of the immigrants are primarily based on social problems, origin, life history, culture, and religion in their home countries, which they have fled because of war and poverty. Some immigrants have poor nutrition, untreated diseases, or such, as a result of a difficult move. In addition, various statuses of stress, malnutrition, chronic diseases, and traces of torture are evident.

Problems also arise during medical examinations performed at the registration centers in the territory of the Republic of Bulgaria. Diagnostics, treatment, and immunizations are obstructed by language barriers and an unawareness by immigrants of the health insurance system of the Republic of Bulgaria. Impediments also exist as a result of cultural and language characteristics during medical examinations of Muslim women.

Concerning the health problems of the refugees, UNHCR-Bulgaria often identify physical and mental problems that differ to those of the common population. These result from persecution, trauma, and having to flee their home. In addition, these people often appear with additional health needs because of restricted access to preventive and prophylactic health programs, continuous deprivation of basic resources necessary for suitable health care, or poor quality of treatment in the first country of asylum.

Solving the health and social problems requires considerable financial resources of the accepting countries. Some migrants do not reveal their medical conditions because they are afraid they will have to stay in the transit country for treatment and this poses risks to the health of the local people in terms of epidemic outbreaks and spread of diseases that are atypical of the region.

A large part of the refugees are people arriving from territories of military action and thus, bear the effects of trauma that are durable on their character. Some have suffered violence, lost relatives, and homes, exposing them to risks of mental or psychosomatic diseases or post-traumatic stress disorders that could accentuate with continuous stay in refugee camps. These people need specialized medical, social, psychological, and legal support.

On the basis of the abundant experience of the International Organization for Migration (IOM), the European Commission developed a Handbook for evaluating the health status of refugees and migrants in the EU/EEA by medical professionals when preparing health evaluations of migrants. This provides guidance for physicians to establish the presence of diseases requiring immediate or subsequent care when evaluating the health of migrants at places lacking diagnostic maintenance, apart from sets of rapid testing (European Commission, 2015). 
This Handbook assists physicians in regards to:

- The overview of the process of health evaluation of migrants;

- Guidance with regards to the conditions that are significant for the health evaluation (a list of parameters);

- A standardized procedure to obtain an expedient, accurate, and thorough gathering of information; and

- The complete protocol for preparing an evaluation of the health status that includes:

- Compiling the medical history, including vaccination status;

- Results of physical examination, including vital signs;

- Basic evaluation of mental health; and

- Specifying the needs of subsequent care or treatment.

The Handbook of the European Commission recommends the evaluation of a migrant's health status be performed on a voluntary basis, fully observing the right of the patient to confidentiality; to adhere to the national mechanisms of reporting, namely declaring diseases which threaten public health; to be performed by qualified medical professionals, acquainted with the culture of the respective persons; and to be treated as an opportunity for undertaking preventive measures, including carrying out consultations and or the provision of health education (European Commission, 2015).

With regards to the risk of outbreak of infectious diseases, immigrants should have the same level of protection as local people, including with regard to diseases preventable by routine vaccinations (European Commission, 2015).

In a joint declaration on the common principles for vaccination of refugees, asylum seekers, and migrants in the European region, the UNHCR-Bulgaria, United Nations Children's Emergency Fund (UNICEF), and WHO emphasized that:

the chronic health problems of refugees, asylum seekers and migrants are basically similar to those of the population of the accepting countries. The physical and psychological burden, however, which is connected with the escape from their countries and the long and difficult travel they have undertaken enhances the common health risks. Factors, as for example the move of large groups of people, shortage of water, unsuitable shelter and hygienic conditions enhance the risk of infectious diseases. The children are especially susceptible to sharp medical conditions, such as respiratory diseases, diarrhea and dermatological infections. (WHO-UNHCR-UNICEF, 2015)

Additionally, it was revealed that "children not yet vaccinated are those most at risk of acquiring vaccine-preventable diseases since the vaccination programs in their countries of origin have been interrupted as result of civil turmoil and wars" (WHO-UNHCR-UNICEF, 2015).

It was recommended that the refugees, asylum seekers, and migrants are vaccinated without excessive delay according to the national immunization schedule of the country in which they are expected to stay longer than one week, with priority for measles, mumps, and rubella (MMR), and polio vaccinations (WHO-UNHCR-UNICEF, 2015). In addition, every vaccinated child or person, taking care of the abovementioned need documentation for their vaccine shots (WHO-UNHCR-UNICEF, 2015).

\section{Conclusion}

In the modern globalized world, the enormous resettlement of human masses from economically poor regions continues. The enforcement of a unified policy of European countries on migration issues will create conditions that regulate the migrant influx, improve the process of integrating asylum seekers, and avoid threats to the populations of accepting countries.

The Republic of Bulgaria, as a transit country on the route of migrants to Central and North Europe, is subject to migration pressure. The state has formulated efforts to accept the migrants and solve part of the health and social problems of asylum seekers, while observing the international standards. It is established that the main problems in the adaptation of migrants are connected with their sociocultural, ethnic, and religious belonging, and their endeavor to settle in economically well-developed European countries. Their poor health status and reluctance to undergo medical treatment and adhere to Bulgarian health laws are other problems that endanger the lives of Bulgarian citizens. 


\section{References}

Bulgarian National Contact Point for the European Migration Network, (2014). Annual report 2014 on migration and asylum policy in Bulgaria (Part 2) Retrieved March, 01, 2016, from http://ec.europa.eu/dgs/home-affairs/what-wedo/networks/european_migration_network/reports/docs/annual-policy/2014/03a_bulgaria_apr_2014_part2_final.pdf

Council of Ministers of the Republic of Bulgaria, (2015). Natsionalna strategiya v oblastta na migratsiyata, ubezhishteto i integratsiyata (2011-2020) [National Strategy on Migration, Asylum and Integration (2011-2020)]. Retrieved March 01, 2016, from http://www.strategy.bg/StrategicDocuments/View.aspx?lang=bg-BG\&Id=670

European Commission, (2014a). Politikite na Evropeřskiya sŭyuz, Migratsiya i predostavyane na ubezhishte. [European Union policies, Migration and Asylum]. doi:10.2775/66163. from http://europa.eu/pol/pdf/flipbook/bg/migration_bg.pdf European Commission, (2014b). Obshta evropeřska sistema za ubezhishte .[Common European Asylum System], doi:10.2837/60718, from http://ec.europa.eu/dgs/home-affairs/e-library/docs/ceas-fact-sheets/ceas_factsheet_bg.pdf European Commission, (2015). Narŭchnik za otsenka na zdravoslovnoto sŭstoyanie na bezhantsite i imigrantite v ES/EIP. [Evaluation Handbook health state refugees and migrants in the European Union and European Economic Area]. DOI:10.2875/284166

State Agency for Refugees with the Council of Ministers. (1993). Agreement Between the United Nations High Commissioner for Refugees and the Government of the Republic of Bulgaria, Retrieved March 28, 2016 from http://www.aref.government.bg/?cat=25

The State Agency for Refugees with the Council of Ministers, (2016). Справка за месец Януари 2016г [Information for the month of January 2016] . Retrieved January, 29, 2016 from http://www.aref.government.bg/?cat=8

UNHCR, The UN Refugee Agency Bulgaria. (2015). Globalni tendentsii.[Global trends]. Retrieved June, 17, 2015 from http://www.unhcr-centraleurope.org/bg/news/2015/globalni-tendencii.html

WHO-UNHCR-UNICEF, (November, 2015). SZO-VKBOON-UNITSEF (noemvri, 2015). Sŭvmestna deklaratsiya otnosno obshtite printsipi za vaksinatsiya na bezhantsi, tŭrseshti ubezhishte litsa i migranti v Evropeěskiya region na SZO. [WHOUNHCR-UNICEF (November, 2015). Joint Declaration on common principles for vaccination of refugees, asylum seekers and migrants in the WHO European Region]. Retrieved March 13, 2016, from http://www.unicef.bg/bg/article/WHOUNHCR-UNICEF-Joint-Statement-on-general-principles-on-vaccination-of-refugees-asylum-seekers-and-migrants-in-theWHO-European-Region-November-2015/971

UNHCR, (2009). Belezhki na VKBOON vŭrkhu integratsiyata na bezhantsite v Tsentralna Evropa. [UNHCR Note on Refugee Integration in Central Europe]. Retrieved March 01, 2016, from http://www.unhcrcentraleurope.org/_assets/files/content/what_we_do/pdf_bg/promoting_integration/UNHCR-Integration_note-BUL.pdf 